\title{
Sustainable architectural education, between theory and prac- tice- the case of Lesser Poland
}

\begin{abstract}
:
The balance between theory and practice in architectural education is a permanent element of the discussion on teaching architecture. The article discusses the method of implementation of practical knowledge of the architectural profession at Poland's largest department of architecture Cracow University of Technology. Showing the subsequent stages of the education process on the way to obtaining authorization to independent design in Poland. Against this background, the didactic methods used in the initially experimental subject and now regular one taught at the Faculty of Architecture of the Technical University of Cracow together with the Chamber of Architects of the Republic of Poland ${ }^{1}$ since 2018 are discussed. The results of this collaboration and the didactic effects are discussed. The experience of adapting methods for remote education in connection with the pandemic of Covid-19 is also presented. In conclusion, because of the obtained results in response to the legal changes introduced by the State, the proposed new model of professional practice is discussed which, in the coming years, will cover all architecture universities in Poland.
\end{abstract}

Keywords: architecture; education, practice

\section{Introduction}

Education is a set of activities and processes aimed at imparting knowledge, shaping certain qualities and skills. The term is derived from the Latin word educatio, meaning upbringing, education [1].

Traditionally three levels of education are distinguished: basic - also called elementary, secondary, being preparation for higher education, and tertiary. After graduation, students may earn further academic degrees, which culminate in earning the title of professor. These are the next levels of education. We also have postgraduate studies organized by universities and scientific units, which serve to specialize, broaden, and update the knowledge acquired during the university studies. Finally, lifelong learning, designed for those who already have formal education, and often organized by professional self-governments, is a characteristic feature of developed societies. At every level, education enables active participation in the evolving world by understanding the mechanisms that run it. However, nobody is ever fully educated, both for reasons within us and due to the dynamics of change around us. Therefore, it is important to stress that education is a continuous process, leading to the fullest possible knowledge in each area.

Architectural education is subject to the same general rules, and additionally has its own specificity associated with our profession. In Poland, in terms of formal and institutional aspects, it begins with the beginning of higher education, and ends with obtaining the right to independently practice the profession.

This period constitutes the main subject of cooperation between universities educating architects and the Chamber of Polish Architects. This has been reflected in legal regulations [2], as under Art. 2.1 of the Architects and Civil Engineers Professional Self-Government Act; "the practice of the profession of architect consists in contributing

1 IARP 
to culture through architectural design of buildings, their spatial surroundings and their execution, supervision of the process of their construction and architectural education." Under Polish law, only members of the Chamber of Architects may prepare designs independently. Consequently, to design independently, after obtaining a license, architects must join the Chamber of Architects. The Chamber ensures the standards of the architectural profession and the purpose of the introduced course was to raise awareness of the issues it addresses.

So far, the model of architectural education was split into two stages, the first of which took place entirely at universities $(\mathrm{U})$ and ended with obtaining a master's degree, preceded by obtaining the degree of engineer. On the other hand, professional practice after graduation and the final exam for the design license were the domain of the IARP (I). The architect's (A) educational scheme (A) was as follows: $U+I=A$. Within this model, the Polish Chamber of Architects participated in education in the defense of engineering and master diplomas, to a limited extent and in an organized way. At the Cracow University of Technology, together with the Regional Chamber, an experimental subject Negotiations, i.e., practical aspects of the architectural profession, has been offered at the second-degree level since 2018.

\section{Materials and Methods}

According to the data of the Ministry of Science and Higher Education, there are 28 universities educating architects [3], and the number of students taking their first year of studies reaches 3,500, respectively about 2,000 on bachelor's degree courses and about 1,500 on master's degree courses.

On the other hand, in recent years, about 1,000 architecture students take the licensing examination annually. Obtaining independence in design is not only a formal requirement, but it also opens an extraordinary and unique opportunity for legitimate architects to implement their own designs, whose quality is the actual measure of the entire education process.

This stage is reached by approximately $50 \%$ of those starting to study architecture. This percentage may be subject to various interpretations. Some will point to the market realities as the cause of this phenomenon, others will indicate the emigration of the already educated youth, the exam being too difficult, or the choice of other activities within architecture, related to academia, architectural criticism, or administration.

Finding those missing $50 \%$ lost in the education process, who do not become independent architects, is a challenge for the entire education system, i.e., both the universities and the Polish Chamber of Architects. From the point of view of the quality of space, and therefore from the point of view of social needs, it would be expected to reverse these proportions and increase the number of graduates who become independent architects. In this way, funds for education would be spent more efficiently.

In the European Union, the average ratio of qualified architects per one thousand residents is 0.78. In Poland, this ratio is 0.26 and in Italy (the highest in Europe), the figure is 2.08 [4]. Thus, this indicator is clearly lower in Poland than in other European countries. Therefore, its increase is one of the postulates of sustainable education. If we consider the process of synchronization of economies within the EU to be correct, we should expect the value of the coefficient to approach the European average in the coming years. This requires an increase in the number of qualified architects from about 13,000 at present to 29,640 , i.e., by 16,640 . In this perspective, we may expect at least a doubling of the number of qualified architects. Apart from graduates of Polish universities, the shortage may be partially compensated for by immigration. These data, although estimated, show the trends and challenges facing architectural education in the coming years.

Of course, it is possible to imagine a situation that the numbers would not change. Therefore, perhaps in the education system with the division into two-stage studies at the second stage, profiled programs should be introduced for professional, scientific, or administrative purposes. This would correspond to the current number of those who decide to pursue a professional career and where the remaining university graduates end up 
after graduation. For example, the largest employer of architects in Cracow is the Faculty of Architecture at the Cracow University of Technology, followed by the Faculty of Architecture of the Municipality of Cracow, and then by architectural firms, the vast majority of which are practices of a few people [5].

The outlined educational perspective and its scale are correct against the background of the Chamber's planned activities, which are restricted by territory to Poland. However, the issue of architectural education has a much broader international dimension associated with the processes of globalization. For example, the fewest authorized architects per 1,000 residents are in China, where their ratio is 0.002 , which creates an enormous need for education in this area. Noteworthy is the fact that this need has been correctly recognized in Poland. Therefore, we should support the initiative of the Bialystok University of Technology, Cracow University of Technology, and Tianjin-Chengiin University, i.e., the establishment of the International Institute of Engineering at Chengjian University in Tianjin, whose syllabus includes architectural education.

A similar challenge was faced a decade ago by the Persian Gulf countries, where there was a shortage of qualified architects. Then, this fact was not noticed and properly made use of in Poland. Today, several universities from France, the U.S. and the UK operate in this area.

The discussion about architectural education in Poland, which has been going on for years, based on the experience gained from the cooperation so far and the results of licensing examinations, has called for greater participation of practitioners, members of the Polish Chamber of Architects, in the education provided by universities. It was also suggested that homogeneous studies be introduced, with no division into first- and second-degree courses, as well as obligatory teaching of design subjects by authorized architects. These actions were to be pro-quality in nature. It was pointed out that during the seven semesters, it is impossible to train an architectural engineer, and such a title is given to bachelor's degree holders.

In 2019, the Ministry of Education issued a document defining new standards of architectural education at universities with a 3-year perspective of its implementation. In the coming years, according to the new standards, students will visit architectural studios for one semester during their studies to learn the practical aspects of the profession under the guidance of IARP members. The minimum duration of internship has been extended from the current minimum of one month to one semester. It is the fulfillment of the IARP's demand and the result of high evaluation of effects of all semester internships, which were conducted in the previous system at the Faculty of Architecture, Silesian University of Technology.

The effect of introduction of new regulation on educational standards is the change in architectural education scheme from $\mathrm{U}+\mathrm{I}=\mathrm{A}$ to $\mathrm{U}+\mathrm{I}+\mathrm{U}+\mathrm{I}=\mathrm{A}$. The iteration expressed therein creates an opportunity to build a more balanced and integrated with practice model. A whole semester of internships under the supervision of members of the Polish Chamber of Architects allows for a wide participation of the organization in the education of the young generation of architects. Their scope will be correlated with the currently prepared by the IARP new standard of professional practice taking place between studies and the examination for the qualifications.

The second postulate of the IARP concerning homogeneous studies has also been partially fulfilled. The regulation allows for both one-tier and two-tier studies. As a result of such formulation of the law, most universities in Poland have remained in two-tier system; only three faculties are considering the introduction of one-tier studies. The regulation on standards also increased the number of design classes, which was welcomed by the Chamber of Architects of Poland as a pro-quality factor.

However, the issue of increasing the number of practitioners in design studies has not been resolved at the national level. Hence the idea of a systemic solution to this problem through a regional experiment. Its aim was to balance education in terms of practical and theoretical knowledge.

\section{Results}


This experiment emerged in the Lesser Poland Region in activity of the Lesser Poland Regional Chamber of Architects ${ }^{2}$ and the Faculty of Architecture of the Cracow University of Technology ${ }^{3}$.

\subsection{Human resources}

The 2018 pilot syllabus was run by 3 chamber members, including one polytechnic professor, for a group of about 20 students, as an optional course. The course teachers had to be members of the chamber of architects, which guaranteed that they would be actively practicing architects. The pilot study allowed for acquiring experience necessary to define the students' needs and their interest in the classes related to the architectural profession. As a result of good reception among students and support of the architecture faculty authorities, the idea of creating a new course in the study syllabus, dealing with practical aspects of the profession, taught by professionally active architects, members of Lesser Poland Regional Chamber of Architects, was put forward. The project was accepted by both the Council of the Faculty of Architecture at the Cracow University of Technology and the Council of the Lesser Poland Regional Chamber of Architects, which paved the way to realization of a full-scale course, this time comprising all students of the 7th semester, i.e., 220 people in the first year, and 270 in the following year. The organizational structure was flexibly adapted to the nature of the classes. The basic seminar team consisted of 10 people. All presenters were members of the Chamber of Architects. Five were employees of the Department of Social and Service Architecture of the Faculty of Architecture at the Cracow University of Technology, and five were delegated from the Chamber of Architects. In addition, 10 architects gave lectures. Each lecture was prepared in cooperation with a researcher from the Cracow University of Technology to meet the methodological requirements. In the final stage of the course, during the last two weeks of the course, when conducting the laboratories on site, the team was supplemented by 15 architects from the Architectural Chamber, which gave the total number of 25 lecturers.

The number of student groups for individual classes varied from 270 persons for lectures, through 25 persons for seminars, to 12 persons for on-site laboratories.

The syllabus covered the maximum number of 270 students and about 30 qualified architects, providing a range of interactions aimed at learning about the architectural profession in its many facets. Architects involved in the Chamber or in practical activities were invited to prepare issues, such as:

- functioning of the Chamber - Chairman of the District Chamber of Architects;

- planning and building permit issues - Architect of the City of Cracow;

- conduct of disciplinary proceedings - Professional Ombudsman of the Chamber;

- Chairperson of the National Disciplinary Court;

- conducting proceedings for granting authorizations - Member of the District Qualification Commission dealing with granting authorizations;

- drafting new laws on architecture and architects - Member of the National Chamber Council;

- conducting administrative proceedings related to town-planning or architectural decisions - Officials of the Architecture Department of the City of Warsaw;

- regulatory update - Editor of the Chamber's website;

2 One of the 16 Regional Chambers of Architects making up the National Chamber of Architects.

3 The largest Polish department educating architects. 
- insurance for architects and valuation of design works Members of the Chamber Team dealing with the conditions of practicing the profession;

- role of architects on construction sites - Architects specialized in supervising construction sites;

The selection of lecturers, seminar participants and laboratory instructors ensured the transfer of practical and up-to-date knowledge on the issues discussed, and was of key importance for the quality of the syllabus.

\subsection{Syllabus}

The original syllabus entitled "Negotiations - Practical Aspects of the Architectural Profession" was prepared and accepted. The name referred to the essence of the profession of the architect being a person who engages in dialogue and negotiation with all participants of the process of design and creation of space. The syllabus was inaugurated in the summer semester 2019/2020.

The syllabus covered issues related to the practice of the profession concerning the following topics:

- the role and place of the Chamber of Architects in architectural practice;

- path to acquiring the license;

- rules of professional ethics;

- jurisdiction in the Chamber of Architects;

- legal conditions of the project process;

- knowledge about real estate for architects' needs;

- authorship supervision and the architect's role on the construction site;

- practical aspects of urban planning and related decisions;

- project documentation, its structure and scope;

- valuation of design studies;

- insurance for architects;

\subsection{Teaching resources}

Lectures, seminars, and laboratories served as the vehicles for this syllabus. During the semester, 12 lectures, 24 seminars, and 22 laboratory meetings were held at selected facilities. Over the course of the syllabus, students listened to 12 lectures and participated in an equal number of seminars on lecture topics. Each student sat an opening exam and a closing exam. This allowed for assessment of knowledge of the topics discussed at the beginning of the syllabus and after its completion.

The lectures and seminars took place at the university and the laboratory classes were held in architects' studios and on construction sites.

The teaching materials, lectures, exams, etc. were prepared by the practicing lecturers and reviewed by the academic staff from a methodological point of view. In the first stage, which lasted about 2.5 months, immediately after each lecture for the whole group there was a division into seminar groups of 20-25 persons. In those groups, the issues 
raised during the lectures were discussed on an ongoing basis. The lecturers shared their professional experiences related to the given topics with the students, in accordance with the outlines prepared by the consecutive lecturers. To coordinate the administrative tasks of the syllabus, there were two assistants employed by the university and two members of the Chamber. During the on-site laboratories, the original design documents of the architects in charge of the course were analyzed. The analysis was focused on showing the relationship between the realized space and the documentation prepared for this purpose. The students prepared documentation forms from their visits to the construction sites including descriptions, sketches, and photos.

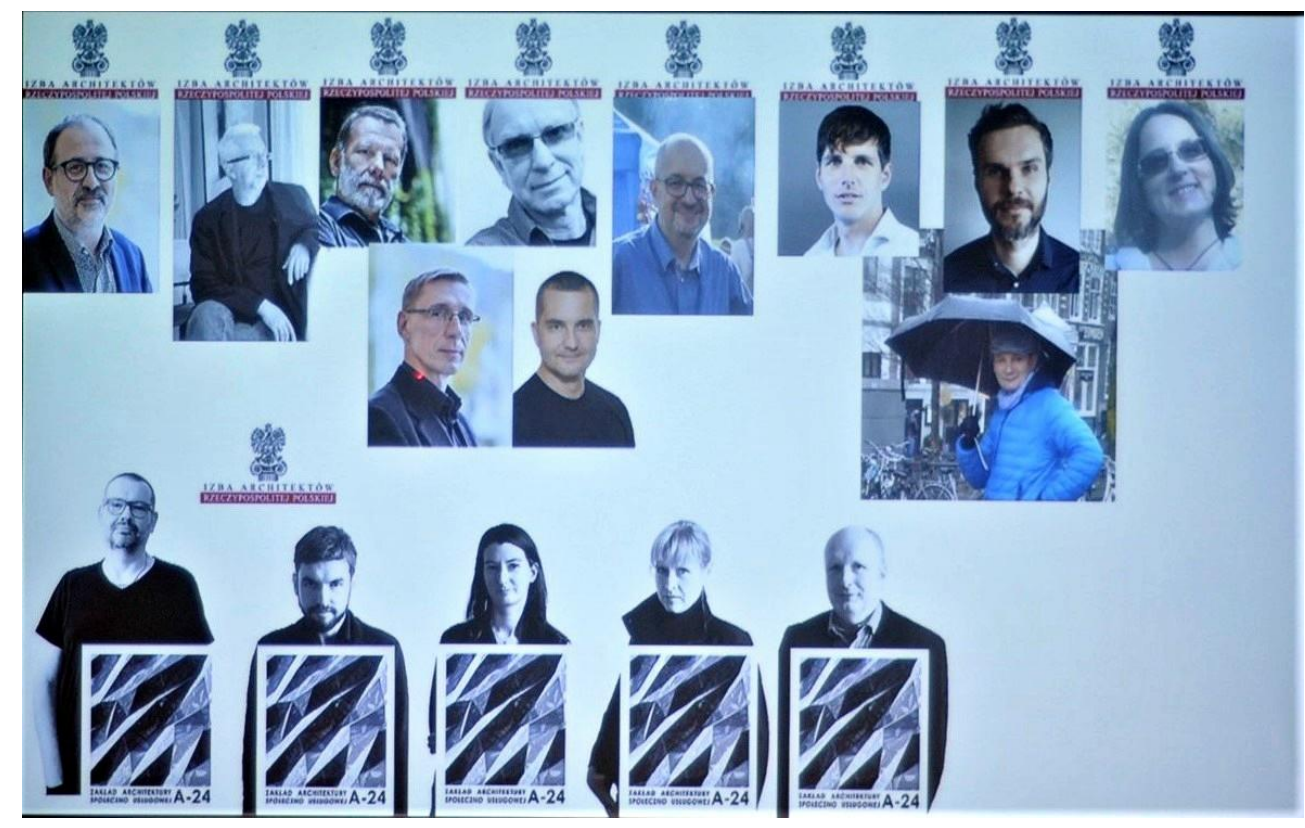

Figure 1 Teaching team.

After the first year of the syllabus, the Chamber of Architects published a handbook based on the issues presented in lectures and laboratories. There were selection tests at the beginning and end of the classes.

This subject also influenced the functioning of the Chamber of Architects, as it allowed for establishing personal relations between future employers and students. A step in this direction was the system of student practice in the Chamber of Architects, which was introduced in Poland for the first time. Students may use a special website for this purpose [6].

\subsection{Remote education oportunity vs threats}

The next year of running the syllabus was in lockdown and remote mode. The inauguration and two lectures were the only ones held in the previous mode. The transition to the remote mode also caused a two-week break in classes. Once classes resumed, lectures were held online using social media. To maintain contact and study discipline, each seminar ended with a test. As a result, the educational progress of the students was much more predictable. At the same time, however, the main advantage of the syllabus - direct contact with the practicing architect - was severely limited and the social media discussion seminars lacked the traditional interaction. The phenomenon of alienation between the instructors and students was noticeable. An important issue was also the control of the self-efficacy of work. To this end, several experiments were carried out, mainly shortening the time for answering test questions or adjusting the activity intervals of test forms. Another idea was to randomize questions within a prepared pool of questions. There was also a significant change in teaching loads within the teaching team. In the 
traditional model, the workload during seminars was symmetrical, whereas in the testing-based model, the workload was asymmetrical. The workload was highest for test developers, as well as for social media managers and remote administrators.

In the no-meeting situation, the biggest challenge was to conduct labs, i.e., site visits combined with documentation analysis.

Due to the pandemic, many students remained at home in their hometowns outside Cracow. Hence, in addition to the impossibility of meeting, there was also no possibility of unifying the subject matter in the traditional venue of the university. This problem was solved by formulating independent tasks that could be carried out individually by students at their place of residence, and which concerned buildings being constructed in their vicinity. The first task concerned the analysis of the content and form of information required by law to be placed on construction sites (building site signs); the other one concerned the principles of organization of the building site and its surroundings in terms of safety. The collected materials were then discussed in seminar groups. These activities revealed a new potential opportunity which is provided by the mass compilation by students while the subject of data concerning information about realized construction sites and their organization, which may allow to improve safety of construction sites.

At the same time, however, an important advantage of the syllabus, i.e., contact with the author of design documentation and this documentation on the realized object, could not be fulfilled. In the science of architecture, which is a material art, this is a serious drawback. Distance design methods have already been described many years ago and can be successfully used in education [6]. However, it requires standardization including, for example, access to the design documentation and its visualization in digital form. A change to include such access at the time of syllabus implementation was not feasible. In future, this will become possible as access to digital building model in Poland based on BIM becomes standardized. Until then, hybrid methods must be used in practice and education in the analysis of design documentation during construction implementation. Paradoxically, however, the necessity to look for a virtual dialogue Paradoxically, however, the necessity to search for a virtual dialogue among the participants of the design process enforced by the pandemic is a chance to modernize the methods of teaching which so far lacked adequate incentives.

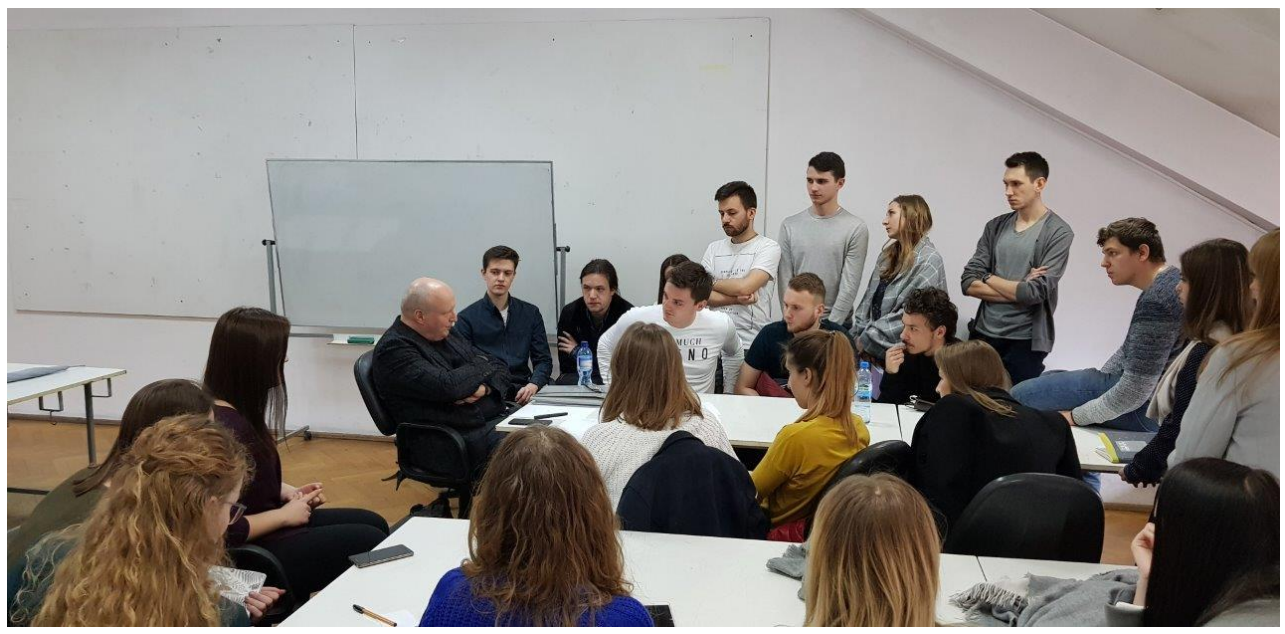

Figure 2 "Negotiation" - a traditional seminar group, academic year 2018/2019. Photo: Lesser Poland Chamber of Architects 

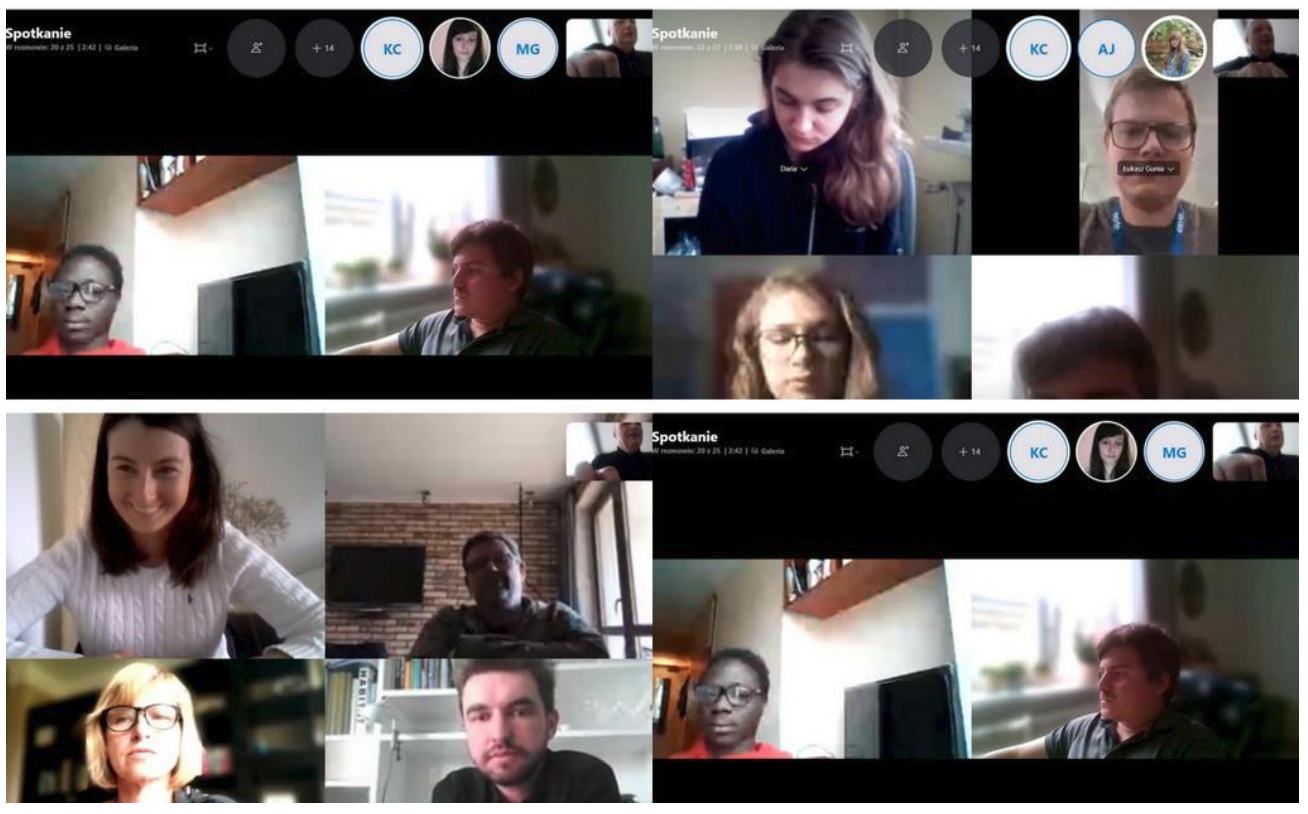

Figure 3 “Negotiations” - a virtual seminar group, academic year 2019/2020. Photo by Kazimierz Butelski

Kiedy projektant może prowadzić nadzór autorski?

235 odpowiedzi

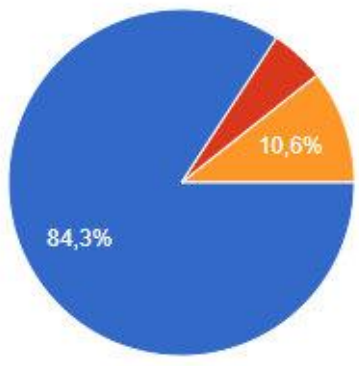

Zawsze, podczas całego procesu budowlanego.

- Tylko na wezwanie Inwestora

lub kierownika budowy

Po podpisaniu umowy o peinieniu nadzoru autorskiego

Kto dokonuje kwalifikacji zmian na budowie?

235 odpowiedzi

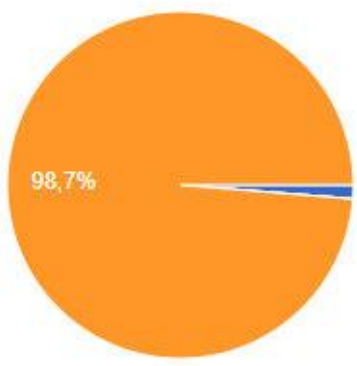

Inspektor nadzoru inwestorskiego lub Kierownik budowy

- Inwestor

Projektant

Figure 4 "Negotiations" - a visualization of virtual test results. Questions: When the architect can supervise the construction site? Who performs the qualification of changes on the construction site?

\section{Discussion}




\subsection{Theory vs practice.}

Numbers are important, but the number of students says little about the quality of education and its model. This should be kept in mind in view of the expected increase in the number of qualified architects. One of the ills of Polish universities is the fragmentation of the teaching process and the fragmentation of subjects, as well as the lack of a permanent place to work on a project and the resulting lack of teamwork. Can this be remedied, and if so, how? To this end, it seems worthwhile to use internationally proven organizational models based on the assumption that:

- design is a team and multi-discipline activity in which a qualified architect leads the entire team;

- projects are created in studios, which are the place for exchange of ideas between team members and consultants.

With these assumptions, education of future designers should reflect the rules of creating architectural projects. Therefore, it should be organized around a project that integrates all educational issues (lectures, laboratories, etc. are part of design consultations);

- organized in a studio (design studio), i.e., the student's permanent work place;

- performed as a team with the participation of specialists and consultants;

- conducted by members of the Polish Chamber of Architects, which guarantees participation of professionally active architects.

All the above principles are realized by the concept of a design studio. It is a place where projects are carried out, ideas are confronted and theories are learned, it is a method of communication within the interdisciplinary team, as well as a method of work, and a proven system of organizing architectural education at all the world's leading universities of architecture, such as TU Delft, ETH in Zurich, UCL in London, MIT, Harvard University, NUS, HKU, UBC in Vancouver. As these examples show, the concept is universal and country independent.

It is also open to modifications due to the emergence of new workflow systems, which is particularly relevant in the current pandemic situation. The physical design studio is relatively easy to transform into a virtual one (VDS, Virtual Design Studio) while maintaining the primacy of design as the leading task of organizing architectural education. Work on VDS was conducted many years ago at MIT, HKU and ETH, and the design methods developed then are easy to implement in an integrated virtual environment.

Acquisition of skills resulting from working in a design studio at the university will allow students and later graduates to effectively benefit from professional internships during and after their studies. The activities of the academic world and the Chamber are therefore complementary and should be synchronized for the best educational results.

\subsection{Innovations}

However, we should not forget about the transfer of knowledge and the latest discoveries in the broad field of architecture from universities to the professional community. This includes the particularly important role of scientific research and new technologies and related experiments that take place at universities. One of the dynamically developing fields in the world in recent years are information technologies, within them $\mathrm{BIM}$, and consequently fabrication. In the latter field, which is revolutionizing building design methodologies by moving directly from a model of a building to its individualized final form without traditional drawings, four global academic centers are leading the way: ETH in Zurich, UCL in London, MIT and IAAC in Barcelona. It should be expected that students educated at Polish universities will introduce these modern design methods in the studios where they will practice. Since information technology and robotization are capital intensive, we may assume that in the future there will also be cooperation between the Polish Chamber of Architects and universities in acquiring them for both professional and academic purposes. 


\subsection{Pre- and post-secondary specialty education}

Nevertheless, we should not lose sight of pre-study and post-license education, because only such a perspective permits us to appreciate how difficult and complicated the issue we face is. These two less formal stages are equally important for the results of the whole process as those traditionally associated with architects' education. The importance of the first one should interest and sensitize future potential architecture students to reading and experiencing space as well as familiarize them with the dictionary of terms used to describe it. This shaping of social sensitivity in relation to the space we live in will allow, on the one hand, for the emergence of future potential professionals and, on the other hand, for the shaping of conscious recipients. Perhaps this second factor will turn out to be decisive, as architecture should be perceived in social terms, which in democratic countries requires consensus built on knowledge. Moreover, architecture is a social art because its creation is the result of team activity, in which the architect plays a key role - a conductor orchestrating the collective effort of the many people involved.

Informal architectural education begins at our birth and ends when we pass away. Architecture accompanies our entire lives. In this sense, architecture is an "unavoidable art." This term was used by Professor Witold Cęckiewicz at the 1980 Congress of Polish Culture to indicate the importance of the role of the quality of architecture in the context of other arts, such as literature, music, painting, or film, which require active participation but also allow for conscious resignation. Architecture does not offer such a choice, hence the concern for its quality must guide all our actions as co-responsible for the quality of space, as architecture is an image of the entire society into which it is created.

\section{Conclusions}

In 2019, the Regulation of the Minister of Science and Higher Education of 18 July 2019 on the standard of education preparing for the profession of architect [7] entered into force. The implementation of this law in relation to student practice will begin in 2022. For the first time in history, the Polish Chamber of Architects has been designated as an institutional partner in architectural education for universities and colleges, and the curriculum is set to increase the number of hours devoted to design. The entire semester of architectural education will take place in the form of practice under the supervision of the IARP members in architectural studios. The training will not only be extended ${ }^{4}$, but also improved in terms of merit, as the students will be taught by architects who are professionally active members of the Chamber of Architects. The new system is an element of adjustment of the education process to the requirements of the labor market and is intended to improve the quality of teaching, but above all - to give the students a substantial measure of practical skills and professional knowledge.

As part of discussions between the Chamber of Architects and the University, a proposal was put forward to develop an electronic practice selection model, based on data exchange. The purpose of the proposed model is to connect the database of qualified architects, members of the Chamber of Architects, with the database of students obliged to practice, which is available to universities, based on appropriate bilateral agreements. As a summary of these meetings, based on the discussion so far and the good practices presented, a practice placement model has been proposed, in cooperation with the Chamber of Architects (having 13,000 members) for approx. 1,500 students annually.

The model of practice assumes of common access to practice in Poland by students at Polish universities with patrons - members of the IARP. This will be carried out based on cooperation agreement between the university and the Polish Chamber of Architects (to implement the provisions of the above-mentioned regulation), through our IT system. All application documents and those confirming the training will be generated in the system. The student will be able to submit an unlimited territorial application for the practice and obtain confirmation of its completion within the period specified in the

${ }^{4}$ Until now, only one month was obligatory. 
regulation. When confirming the internship, the patron will certify that the substantive scope of the internship complies with the internship portfolio and the time scope complies with the regulation. In the absence of such compliance, they may refuse to confirm the internship. Members of the Chamber of Architects, as patrons, do not evaluate students; this is the domain of the university. The selection of the intern by the patron - a member of the Chamber - will be made in the computer system, based on a portfolio prepared by the applicant of projects completed so far during study. The standard application portfolio and templates for other application documents will be defined soon. However, it is known that the application portfolio will contain a graphic and descriptive part. Confirmation of the internship by the patron will also take place in the computer system based on the internship portfolio. All documents in this regard will be specified at a later stage. The practice portfolio will consist of a graphical and a descriptive part.

The system organized in this manner is universal, equal, and non-discriminatory regarding the place of study, type of university, nationality, race, gender, religion, and beliefs, thus enabling everyone to complete the internship on merit alone. This model assumes the autonomy of universities and the Polish Chamber of Architects, who cooperate in the provision of high-quality education.

\section{References}

1 Multiple authors. Słownik Jezyka Polskiego PWN. https://sjp.pwn.pl/slowniki/humanitaryzm.html. Accessed 09 Feb. 2019.

2 The Sejm of the Republic of Poland. Internet System of Legal Acts. 15 December 2000, http://isap.sejm.gov.pl/isap.nsf/download.xsp/WDU20010050042/U/D20010042Lj.pdf. Accessed 25 March 2021.

3 National Information Processing Institute. Nauka Polska. National Information Processing Institute, 25 March 2021, https://nauka-polska.pl/\#/results?_k=81clp0. Accessed 02 April 2021.

4 ACE. Architects Council of Europe. Architects Council of Europe, Brussels, 2018.

5 Butelski, K. Study commissioned by the Dean of the Faculty of Architecture. Manuscript, Cracow, 2016.

6 Wojtowicz J., Butelski. K. “Lessons from Distributed Design Practice.” Digital Architecture, 1st ed., vol. 4, New York , Routledge, 2020, pp. 482-487.

7 The Sejm of the Republic of Poland. Internet System of Legal Acts. July 2019, http://isap.sejm.gov.pl/isap.nsf/DocDetails.xsp?id=WDU20190001359. Accessed 30 March 2021.

This research received no external funding.

The author declare no conflict of interest. 